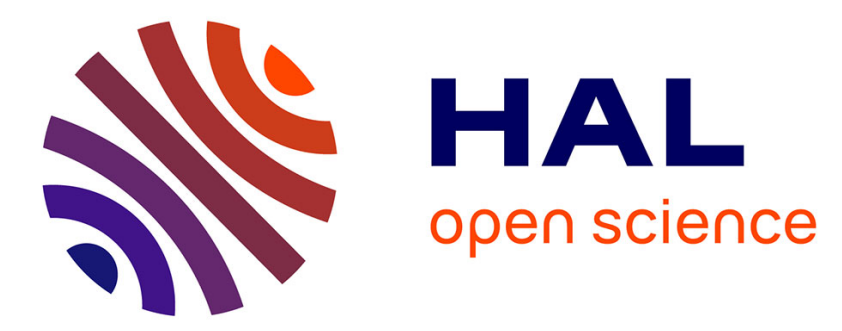

\title{
Commentaries on Viewpoint: Human skeletal muscle wasting in hypoxia: a matter of hypoxic dose?
}

Grégoire P Millet, Tadej Debevec, Franck Brocherie, Olivier Girard, Vincent Pialoux

\section{- To cite this version:}

Grégoire P Millet, Tadej Debevec, Franck Brocherie, Olivier Girard, Vincent Pialoux. Commentaries on Viewpoint: Human skeletal muscle wasting in hypoxia: a matter of hypoxic dose? . Journal of Applied Physiology, 2017, 122 (2), pp.409. 10.1152/japplphysiol.01084.2016 . hal-01793570

\section{HAL Id: hal-01793570 https: / hal-insep.archives-ouvertes.fr/hal-01793570}

Submitted on 17 May 2018

HAL is a multi-disciplinary open access archive for the deposit and dissemination of scientific research documents, whether they are published or not. The documents may come from teaching and research institutions in France or abroad, or from public or private research centers.
L'archive ouverte pluridisciplinaire HAL, est destinée au dépôt et à la diffusion de documents scientifiques de niveau recherche, publiés ou non, émanant des établissements d'enseignement et de recherche français ou étrangers, des laboratoires publics ou privés. 


\section{VIEWPOINT}

\section{Commentaries on Viewpoint: Human skeletal muscle wasting in hypoxia: a}

\section{matter of hypoxic dose?}

\section{INFLUENCE OF THE BETWEEN-SUBJECTS AND BETWEEN- HYPOXIC CONDITIONS VARIABILITY IN OXIDATIVE STRESS}

TO THE EDITOR: The authors of the Viewpoint (2) propose that a cut-off point for initiation of hypoxia-induced muscle wasting is $\sim 5,000 \mathrm{~km} \cdot \mathrm{h}$. Although they employ a valuable new metric, incorporating elevation and total exposure time, we previously suggested that it might be better to quantify the hypoxic stimuli by using "saturation hours" (4). This is particularly important given that both (de)saturation and oxidative/nitrosative stress responses to hypoxia are highly variable between individuals and also differ between the types of hypoxia (i.e., hypobaric vs. normobaric) (3). It is well established that the level of desaturation importantly modulates oxidative stress and, moreover, that augmented oxidative stress levels significantly contribute to disuse muscle atrophy by increasing protein oxidation and accelerating muscle protein breakdown (5). In addition, reactive oxygen species were shown to stabilize HIF-1 $\alpha$, independently of hypoxic stimulus, which likely plays a role in downregulation of muscle mass, as outlined in the Viewpoint (2). The close relationship between oxidative/nitrosative stress and muscle atrophy observed in cachexia and sarcopenia patients (1) lends further support to this notion. The individual variability in responses to hypoxia must therefore be taken into account to enhance our understanding of the mechanism underlying hypoxia-related muscle wasting. To conclude, it seems unlikely that a critical hypoxic threshold for muscle wasting could be defined solely on the "external" hypoxic dose, without accounting for the between-individual variability in desaturation (i.e., hypoxic stimuli) and/or oxidative/nitrosative stress responses.

\section{REFERENCES}

1. Bowen TS, Schuler G, Adams V. Skeletal muscle wasting in cachexia and sarcopenia: molecular pathophysiology and impact of exercise training. $J$ Cachexia Sarcopenia Muscle 6: 197-207, 2015. doi:10.1002/jcsm.12043.

2. D'Hulst G, Deldicque L. Viewpoint: Human skeletal muscle wasting in hypoxia: a matter of hypoxic dose? J Appl Physiol. doi:10.1152/japplphysiol.00264.2016.

3. Faiss R, Pialoux V, Sartori C, Faes C, Dériaz O, Millet GP. Ventilation, oxidative stress, and nitric oxide in hypobaric versus normobaric hypoxia. $\mathrm{Med} \mathrm{Sci}$ Sports Exerc 45: 253-260, 2013. doi:10.1249/MSS.0b013e31826d5aa2.

4. Millet GP, Brocherie F, Girard O, Wehrlin JP, Troesch S, Hauser A, Steiner T, Peltonen JE, Rusko HK, Constantini K, Fulton TJ, Hursh DG, Noble TJ, Paris HL, Wiggins CC, Chapman RF, Levine BD, Kumar VH, Schmidt WF. Commentaries on Viewpoint: Time for a new metric for hypoxic dose? J Appl Physiol (1985) 121: 356-358, 2016. doi:10.1152/japplphysiol.00460.2016.

5. Powers SK, Smuder AJ, Judge AR. Oxidative stress and disuse muscle atrophy: cause or consequence? Curr Opin Clin Nutr Metab Care 15: 240-245, 2012. doi:10.1097/MCO.0b013e328352b4c2.
Grégoire P. Millet ${ }^{1}$
Tadej Debevec ${ }^{2}$
Franck Brocherie ${ }^{1}$
Olivier Girard ${ }^{1}$
Vincent Pialoux ${ }^{3}$
${ }^{1}$ University of Lausanne, Switzerland
2 "Jozef Stefan" Institute, Slovenia
${ }^{3}$ Univ Lyon, University Claude Bernard Lyon 1, France

\section{SKELETAL MUSCLE WASTING IN HYPOXIA; A MATTER OF ALTITUDE}

TO THE EDITOR: D'Hulst and Deldicque (1) argue that the severity of muscle atrophy incurred at high altitude is dependent on the combined effect of duration and degree of hypoxia exposure, or "hypoxic dose" (1). We do see a limitation of this concept, as it implies that someone residing in Leuven (altitude: $28 \mathrm{~m}$ ) for 10 years would be subjected to a hypoxic dose of $2,454 \mathrm{~km} \cdot \mathrm{h}$ and incur $5 \%$ atrophy. Although the authors wrote that "it is unknown which parameter, altitude, or time spent at altitude is most decisive in the overall metric of hypoxic dose," our illustration suggests that altitude is the prime determinant. This is further supported by the cut-off point at 4,000 $\mathrm{m}$ in a plot of the degree of atrophy vs. altitude (using the data in Table 1), whereas there was no clear relationship with duration of altitude residence. This cut-off point is likely related to the shape of the hemoglobin dissociation curve, where the oxygen tension at $4,000 \mathrm{~m}$ is such that physiologically significant arterial hemoglobin desaturation occurs (2). We acknowledge that one cannot entirely dismiss the importance of duration of hypoxic exposure, simply because skeletal muscle atrophy can only be noticed some time after net protein breakdown is initiated. However, muscle atrophy will not continue indefinitely, but will reach a new steady state (how otherwise can Tibetans still have muscle?). Finally, other adaptations than atrophy, such as an increase in hematocrit and capillarization, serve to attenuate muscle tissue hypoxia and atrophy (3) during residence at altitude.

\section{REFERENCES}

1. D'Hulst G, Deldicque L. Viewpoint: Human skeletal muscle wasting in hypoxia: a matter of hypoxic dose? J Appl Physiol. doi:10.1152/ japplphysiol.00264.2016.

2. Wagner PD, Wagner HE, Groves BM, Cymerman A, Houston CS. Hemoglobin $\mathrm{P}(50)$ during a simulated ascent of Mt. Everest, Operation Everest II. High Alt Med Biol 8: 32-42, 2007. doi:10.1089/ham.2006. 1049.

3. Wüst RCI, Jaspers RT, van Heijst AF, Hopman MT, Hoofd LJ, van der Laarse WJ, Degens H. Region-specific adaptations in determinants of rat skeletal muscle oxygenation to chronic hypoxia. Am J Physiol Heart Circ Physiol 297: H364-H374, 2009. doi:10.1152/ajpheart.00272.2009.

Rob C.I. Wüst

University of Amsterdam, The Netherlands

Hans Degens

Manchester Metropolitan University, United Kingdom Lithuanian Sports University, Lithuania

COMMENTARY ON VIEWPOINT: HUMAN SKELETAL MUSCLE WASTING IN HYPOXIA: A MATTER OF HYPOXIC DOSE?

TO THE EDITOR: D'Hulst and Deldicque (2) present an interesting Viewpoint that the loss of muscle mass at high altitude is a protective or adaptive mechanism of skeletal muscle to stress. Based on the theory of General Adaptation Syndrome proposed by Hans Selye (4), our body's response to stress such as 
hypoxia is developed through three different stages: alarming stage, resistance/adaptation stage, and de-adaptation stage. In general, the skeletal muscle is anatomically and physiologically overcompensated during the adaptive stage. However, human skeletal muscle wasting in hypoxia mentioned in this paper is actually evident as a de-adaptive response. In other words, high-altitude or prolonged hypoxic stress is overwhelming and the body reaches the de-adaptation stage.

However, the authors make a good point that the dose of hypoxic stress does matter (2). We previously revealed that $\mathrm{Po}_{2}$ cycling has a protective effect on diaphragmatic skeletal muscle via the attenuation of reactive oxygen species and the increase of fatigue resistance (5). In human study, hypoxic exposure during high-altitude training results in increased $\dot{\mathrm{V}}_{\mathrm{O}_{2 \max }}$ in elite endurance athletes (3). Therefore, the dose and duration of hypoxia exposure play a pivotal role in regulating skeletal muscle mass. In contrast to chronic hypoxic exposure, intermittent acute hypoxic exposure combined with resistance exercise could potentially delay muscle wasting and promote muscle growth (1). Future approaches should focus on how to optimize the dose and duration of hypoxia exposure to maximize the skeletal muscle adaptive response without exacerbating skeletal muscle atrophy.

\section{REFERENCES}

1. Deldicque L, Francaux M. Acute vs. chronic hypoxia: what are the consequence for skeletal muscle mass? Cell Mol Exerc Physiol 2: 1-8, 2013. doi:10.7457/cmep.v2i1.e5.

2. D'Hulst G, Deldicque L. Viewpoint: Human skeletal muscle wasting in hypoxia: a matter of hypoxic dose? J Appl Physiol. doi:10.1152/ japplphysiol.00264.2016.

3. Saunders PU, Garvican-Lewis LA, Schmidt WF, Gore CJ. Relationship between changes in haemoglobin mass and maximal oxygen uptake after hypoxic exposure. Br J Sports Med 47, Suppl 1: i26-i30, 2013. doi:10.1136/bjsports-2013-092841.

4. Selye H. Stress and disease. Science 122: 625-631, 1955. doi:10.1126/ science.122.3171.625.

5. Zuo L, Pannell BK, Re AT, Best TM, Wagner PD. Po2 cycling protects diaphragm function during reoxygenation via ROS, Akt, ERK, and mitochondrial channels. Am J Physiol Cell Physiol 309: C759-C766, 2015.10. 1152/ajpcell.00174.2015.

\section{Li Zuo \\ The Ohio State University College of Medicine}

Feng $\mathrm{He}$

California State University-Chico

\section{A DOSE OF 5,000 KM·H OF SEVERE HYPOXIA (AT > 5,000 M ALTITUDE) IS PROBABLY REQUIRED TO INDUCE SKELETAL MUSCLE WASTING IN HUMANS}

TO THE EDITOR: We appreciate the authors' Viewpoint (1) regarding the concept that a hypoxic dose of at least $5,000 \mathrm{~km} \cdot \mathrm{h}$ is necessary to induce skeletal muscle wasting in humans. We agree that both the time of exposure and the level of altitude are critical for inducing a loss of muscle mass. However, in our point of view, a dose of at least $5,000 \mathrm{~km} \cdot \mathrm{h}$ with a minimal altitude of $5,000 \mathrm{~m}$ is probably required. For instance, 8 -wk exposure to 4,100 m altitude (i.e., $\sim 5,500 \mathrm{~km} \cdot \mathrm{h}$ ) did not lead to a significant decrease in skeletal muscle fiber cross sectional area (FCSA) in humans (2). In contrast, 40 days at an average altitude of $\sim 5,500$ $\mathrm{m}$ (i.e., $\sim 5,300 \mathrm{~km} \cdot \mathrm{h}$ ) reduced muscle FCSA by $\sim 25 \%$ (3). Athletes undergoing training camps usually stay at a lower altitude of $\sim 2,500-3,000 \mathrm{~m}$, but not for a period long enough to reach an hypoxic dose of $5,000 \mathrm{~km} \cdot \mathrm{h}$. Still, a dose of at least $5,000 \mathrm{~km} \cdot \mathrm{h}$ at 2,500-3,000 m altitude (i.e., at least 83 and 69 days of exposure, respectively) is likely insufficient to induce significant muscle atrophy because of the limited hypoxic stress. Several physiological factors have been proposed to explain the loss of body weight and muscle mass during prolonged exposure to severe hypoxia, including a reduction of energy intake, nutrient malabsorption, physical inactivity, and parameters related to mountaineering (4). However, loss of appetite and the resulting decreased caloric intake is probably the predominant cause for the muscle wasting at $>5,000 \mathrm{~m}$ altitude (5).

\section{REFERENCES}

1. D'Hulst G, Deldicque L. Viewpoint: Human skeletal muscle wasting in hypoxia: a matter of hypoxic dose? J Appl Physiol. doi:10.1152/ japplphysiol.00264.2016.

2. Lundby C, Pilegaard H, Andersen JL, van Hall G, Sander M, Calbet JA. Acclimatization to $4100 \mathrm{~m}$ does not change capillary density or mRNA expression of potential angiogenesis regulatory factors in human skeletal muscle. J Exp Biol 207: 3865-3871, 2004. doi:10.1242/jeb.01225.

3. MacDougall JD, Green HJ, Sutton JR, Coates G, Cymerman A, Young P, Houston CS. Operation Everest II: structural adaptations in skeletal muscle in response to extreme simulated altitude. Acta Physiol Scand 142: 421-427, 1991. doi:10.1111/j.1748-1716.1991.tb09176.x.

4. Rose MS, Houston CS, Fulco CS, Coates G, Sutton JR, Cymerman A. Operation Everest. II: Nutrition and body composition. J Appl Physiol (1985) 65: 2545-2551, 1988.

5. Tschöp M, Morrison KM. Weight loss at high altitude. Adv Exp Med Biol 502: 237-247, 2001. doi:10.1007/978-1-4757-3401-0_16.

Thomas Chaillou

Örebro University, Sweden

Arthur Cheng

Karolinska Institutet, Sweden

\section{A LESSER MUSCLE HYPERTROPHIC RESPONSE TO RESISTANCE TRAINING BELOW THE HYPOXIC DOSE OF 5,000 KM·H}

TO THE EDITOR: D'Hulst and Deldicque (1) suggest a minimum hypoxic exposure of $5,000 \mathrm{~km} \cdot \mathrm{h}$ for hypoxia-induced muscle atrophy to develop. We (4) found a reduced hypertrophic response to resistance training in chronic hypoxia. Young men performed strength training of the elbow flexors for $1 \mathrm{mo}$, once at 5,050 $\mathrm{m}$ and once with an identical load at sea level. They were in energy balance, lived in comfortable conditions (Ev-K2CNR Pyramid, Lobuche, Nepal), and consumed a similar diet at altitude and at sea level. NMRI quantified muscle cross-sectional area increased less at altitude compared with sea level (11.3 vs. $17.7 \%$ ), whereas muscle-specific tension did not vary. The hypoxic dose of $3,600 \mathrm{~km} \cdot \mathrm{h}$ suggests that the effect of hypoxia on muscle protein anabolism and catabolism balance is already influenced below 5,000 $\mathrm{km} \cdot \mathrm{h}$. As D'Hulst and Deldicque mention, the combination of time and altitude is not necessarily uniform. Furthermore, diet, living conditions, exercise, sleep, fatigue, or nonaltitude illness may be confounding factors (5). Muscle maintenance in hypoxia thus still remains to be better described. The verb "wasting" has a strong negative connotation, and the title of this Viewpoint suggests that muscle loss in hypoxia implies squandering of precious tissue (1). As acknowledged by D'Hulst and Deldicque, there are good reasons to not discard the opposite hypothesis. The reduction in the volume of metabolic costly tissue may actually serve a physiological purpose. In their reviews, Murray and Montgomery (3; see also comment in 2) proposed 
that the loss of body mass at altitude helps the organism to survive in oxygen deprived conditions.

\section{REFERENCES}

1. D'Hulst G, Deldicque L. Viewpoint: Human skeletal muscle wasting in hypoxia: a matter of hypoxic dose? J Appl Physiol. doi:10.1152/ japplphysiol.00264.2016.

2. Kayser B. High altitude cachexia: adaptation instead of deterioration? (Comment on DOI 10.1002/bies.201400042). BioEssays 36: 720, 2014. doi:10.1002/bies.201400084.

3. Murray AJ, Montgomery HE. How wasting is saving: weight loss at altitude might result from an evolutionary adaptation. BioEssays 36: 721-729, 2014. doi:10.1002/bies.201400042.

4. Narici MV, Kayser B. Hypertrophic response of human skeletal muscle to strength training in hypoxia and normoxia. Eur J Appl Physiol Occup Physiol 70: 213-219, 1995. doi:10.1007/BF00238566.

5. Westerterp KR, Kayser B. Body mass regulation at altitude. Eur J Gastroenterol Hepatol 18: 1-3, 2006. doi:10.1097/00042737-200601000-00001.

\section{Bengt Kayser \\ University of Lausanne}

COMMENTARY ON VIEWPOINT: HUMAN SKELETAL MUSCLE WASTING IN HYPOXIA: A MATTER OF HYPOXIC DOSE?

TO THE EDITOR: D'Hulst and Deldicque's Viewpoint (1) proposed that skeletal muscle atrophy during hypoxia in humans would occur if a "hypoxic dose" is reached. Although this has merit to shed light on hypoxia-mediated skeletal muscle effects, we believe that the idea of a "critical hypoxic dose" needs to be further defined. First, the Viewpoint suggests a linear relationship between altitude level and subsequent effects on muscle tissue. However, the level of arterial $\mathrm{O}_{2}$ saturation $\left(\mathrm{Sa}_{\mathrm{O}_{2}}\right)$ in relation to altitude is curvilinear. Furthermore, the effects of normobaric vs. hypobaric hypoxia on $\mathrm{Sa}_{\mathrm{O}_{2}}$ do not seem to be equal (4). Thus the use of $\mathrm{Sa}_{\mathrm{O}_{2}}$ rather than altitude level could be more specific in defining a muscle wasting zone. In addition, hypoxia-induced erythropoiesis appears to depend on the baseline iron stores and hemoglobin mass (3). Therefore, preliminary skeletal muscle and adipose tissue mass could be considered as covariates for hypoxiainduced muscle wasting. We question the relative importance of the altitude level and exposure duration factors and believe altitude severity is a key signal for triggering muscle atrophy. In animal studies, the correlation between skeletal mass loss and altitude level is strong $\left(P<0.001, r^{2}=0.68\right)$ with a significant atrophy occurring above $5,000 \mathrm{~m}$ (2). Consistently, human studies cited in the Viewpoint report this muscle wasting phenomenon above $5,000 \mathrm{~m}$, which suggests that this altitude could represent a critical threshold. These concerns aim to provide future directions to unravel hypoxia-mediated skeletal muscle regulation.

\section{REFERENCES}

1. D'Hulst G, Deldicque L. Viewpoint: Human skeletal muscle wasting in hypoxia: a matter of hypoxic dose? J Appl Physiol. doi:10.1152/ japplphysiol.00264.2016.

2. Favier FB, Britto FA, Freyssenet DG, Bigard XA, Benoit H. HIF-1driven skeletal muscle adaptations to chronic hypoxia: molecular insights into muscle physiology. Cell Mol Life Sci 72: 4681-4696, 2015. doi:10. 1007/s00018-015-2025-9.

3. Lundby C, Millet GP, Calbet JA, Bärtsch P, Subudhi AW. Does 'altitude training' increase exercise performance in elite athletes? $\mathrm{Br} J$ Sports Med 46: 792-795, 2012. doi:10.1136/bjsports-2012-091231.
4. Saugy JJ, Schmitt L, Cejuela R, Faiss R, Hauser A, Wehrlin JP, Rudaz B, Delessert A, Robinson N, Millet GP. Comparison of "Live High-Train Low" in normobaric versus hypobaric hypoxia. PLoS One 9: e114418, 2014 [Erratum, PLoS One 10: e0133091, 2015. doi:10.1371/ journal.pone.0133091]. doi:10.1371/journal.pone.0114418.

\section{François B. Favier \\ University of Montpellier \\ Gwénaëlle Begue \\ Ball State University}

\section{COMMENTARY ON VIEWPOINT: HUMAN SKELETAL MUSCLE} WASTING IN HYPOXIA: A MATTER OF HYPOXIC DOSE?

TO THE EDITOR: We welcome the suggestion by D'Hulst and Deldicque (1) that both duration of exposure and elevation influence the occurrence and extent of muscle wasting in hypoxia. The application of the hypoxic dose metric, proposed by Garvican-Lewis et al. (2), is an interesting proposition but, in our view, too preliminary given the paucity of studies, low subject numbers, and interindividual variability in response. The studies highlighted collectively suggest that muscle wasting occurs only above a threshold average elevation of around $5,000 \mathrm{~m}$ and reliably so above this point. Any dependence upon duration of exposure is harder to establish. Sojourns above $5,000 \mathrm{~m}$ are rarely short in duration, and within those studies hitherto performed above this altitude (durations 35-75 days), there is no clear association between dose and extent of wasting. Exposure duration is key to many aspects of muscle remodeling at altitude (3). Indeed, the stabilization of HIF1 $\alpha$ vs HIF $2 \alpha$, and thus their relative contributions to the cellular hypoxia response, is time dependent (4). However, muscle wasting is likely also influenced systemically by appetitesuppressing effects of hypoxia (5), which may also be time dependent and would probably introduce further interindividual variation. The duration component must also reflect any delay between a molecular response to hypoxia/caloric deficit and the detection of measureable morphological changes, unless molecular techniques are employed. The authors make the important point that future studies should be designed to precisely elucidate the relative contributions of duration vs elevation to muscle wasting. We agree, and reserve judgement on a hypoxic dose threshold.

\section{REFERENCES}

1. D'Hulst G, Deldicque L. Viewpoint: Human skeletal muscle wasting in hypoxia: a matter of hypoxic dose? J Appl Physiol. doi:10.1152/ japplphysiol.00264.2016.

2. Garvican-Lewis LA, Sharpe K, Gore CJ. Time for a new metric for hypoxic dose? J Appl Physiol (1985) 121: 352-355, 2016. doi:10.1152/ japplphysiol.00579.2015.

3. Horscroft JA, Murray AJ. Skeletal muscle energy metabolism in environmental hypoxia: climbing towards consensus. Extrem Physiol Med 3: 19, 2014. doi:10.1186/2046-7648-3-19.

4. Koh MY, Powis G. Passing the baton: the HIF switch. Trends Biochem Sci 37: 364-372, 2012. doi:10.1016/j.tibs.2012.06.004.

5. Murray AJ, Montgomery HE. How wasting is saving: weight loss at altitude might result from an evolutionary adaptation. BioEssays 36: 721-729, 2014. doi:10.1002/bies.201400042.

Andrew J. Murray and James A. Horscroft University of Cambridge 